\title{
JPSE
}

(Journal of Physical Science and Engineering)

\section{Konduktivitas Fluida-Cairan Di Manifestasi Panas Bumi Bukit Kasih Kanonang Sulawesi Utara}

\begin{tabular}{l}
\hline Received \\
27 Oktober 2017 \\
Revised \\
30 November 2017 \\
Accepted for Publication \\
30 December 2017 \\
Published \\
9 Januari 2018 \\
\hline
\end{tabular}

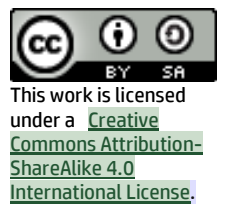

\author{
H Taunaumang ${ }^{1}$, P E Golioth ${ }^{2}$ \\ 1 Jurusan Fisika, Fakultas Matematika dan Ilmu Pengetahuan Alam, Universitas Negeri Manado, \\ Tondano, 95618, Indonesia, \\ ${ }^{2}$ Lulusan Mahasiswa Jurusan Fisika, Fakultas Matematika dan Ilmu Pengetahuan Alam, Universitas \\ Negeri Manado, Tondano, 95618, Indonesia \\ "E-mail: hein.taunaumang@yahoo.com
}

\begin{abstract}
Research on characteristics of fluid-liquid at hot spring water manifestation of Bukit Kasih Kanonang, Kabupaten Minahasa, North Sulawesi have been carried out. The hot spring water manifestation of the Bukit Kasih Kanonang has been known as one of natural tourism object in North Sulawesi. However, the fluid-liquid characterstics at this manifestation location are not yet identified. The aim of this research is to know the chemistry element composition in the fluid-liquid at the hot spring water manifestion Bukit Kasih Kanong and also physical properties such as conductivity and temperature of the fluid-liquid. The identification the element composition in the fluid-liquid has been measured by using XRF (X-Ray fluorescence spectrometry). And the conductivity and $\mathrm{pH}$ were measured using Prolab 2000 Schott Instruments. The experimental results of conductivity measurement and $\mathrm{pH}$, and temperature of fluid-liquid in the three manifestation location are discussed in this article. The experimental result shows that, the $\mathrm{pH}$ value of the fluid-liquid in the manifestion location is categorized as strong electrolit acid. The conductivity value of fluid-liquid is depent on its $\mathrm{pH}$ value. And the $\mathrm{pH}$ value is strongly determined by the Cloride acid composition which dissociates in the fluid-liquid.
\end{abstract}

Keyword: Fluid-liquid, conductivity, Kanonang.

\begin{abstract}
Abstrak
Penelitian tentang karakteristik fluida-cairan di daerah manifestasi panas bumi Bukit Kasih Kanonang, Kabupaten Minahasa, Sulawesi Utara telah dilakukan. Manifestasi panas bumi (mata air panas) Bukit Kasih Kanonang dikenal sebagai salah satu objek pariwisata alam di Sulawesi Utara, namun karakteristik fluida-cairan di lokasi ini belum teridentifikasi. Penelitian ini bertujuan untuk mengetahui komposisi unsur kimiawi fluida-cairan di Manifestasi Bukit Kasih Kanonang dan sifat fisis yakni konduktivitas dan suhu fluidacairan tersebut. Identifikasi komposisi unsur fluida-cairan telah dilakukan dengan menggunakan alat XRF (X-ray fluorescence spectrometry). Pengukuran konduktivitas dan $\mathrm{pH}$ fluida-cairan tersebut telah dilakukan dengan menggunakan alat ProLab 2000 Schott Instruments. Hasil eksperimen pengukuran konduktivitas, $\mathrm{pH}$ dan suhu fluida-cairan untuk tiga lokasi manifestasi panas bumi Bukit Kasih Kanonang telah dibahas dalam artikel ini. Hasil eksperimen pengukuran $\mathrm{pH}$ menunjukkan bahwa karakteristik fluida-cairan adalah elektrolit jenis asam (acid). Nilai konduktivitas fluida-cairan bergantung pada nilai pHnya. Nilai $\mathrm{pH}$ tersebut sangat ditentukan oleh komposisi asam klorida (elektrolit kuat) yang terdisosiasi dalam fluida-cairan tersebut.
\end{abstract}

Kata Kunci: Fluida-Cairan, Konduktivitas, Kanonang.

\section{Pendahuluan}

Fluida-cairan yang ada di lokasi manifestasi panas bumi Bukit Kasih Kanonang Kabupaten Minahasa, Sulawesi Utara sebagai objek penelitian yang menarik dan penting karena Bukit Kasih Kanonang dikenal sebagai salah satu objek pariwisata alam di Sulawesi Utara. Karakteristik fluida-cairan di lokasi ini belum teridentifikasi oleh karena itu penelitian ini penting dan sangat menarik. Fluida- 
cairan di lokasi ini cukup panas dengan suhu di atas $50^{\circ} \mathrm{C}$ dan tampak bahwa didaerah itu mengeluarkan uap sebagaimana ditunjukkan pada gambar 2.2. Air panas ini telah dimanfaatkan oleh masyarakat untuk memasak telur dan milu (jagung). Telur dan milu ini dimasukkan dalam wadah tertentu kemudian direbus dengan cara merendamkannya di dalam air panas tersebut. Bagaimana karakteristik dan apa kandungan fluida-cairan di Manifestasi panas bumi Bukit Kasih Kanonang adalah pertanyaan yang dicari jawabannya melalui penelitian ini.

Penelitian ini bertujuan untuk mengidentifikasi komposisi unsur terkandung dalam fluida-cairan, mengukur konduktivitas dan $\mathrm{pH}$ fluida-cairan di Manifestasi panas bumi Bukit Kasih Kanonang. Pengukuran konduktivitas secara luas telah digunakan dalam industri pengolahan air limbah untuk menentukan tingkat kontaminasi air [1]. Konduktivitas adalah kemampuan suatu larutan, logam atau gas untuk menghantarkan arus listrik. Dalam larutan arus diangkut oleh kation dan anion, sedangkan untuk logam oleh elektron. Kemampuan larutan menghantarkan listrik bergantung pada konsentrasi ion, mobilitas ion, valensi ion dan suhu larutan [2]. Peningkatan suhu larutan dapat menyebabkan kenaikan konduktivitas karena dengan kenaikan suhu larutan akan meningkatkan pergerakan ion-ion dalam larutan tersebut.

Identifikasi komposisi unsur fluida-cairan berasal dari manifestasi panas bumi Bukit Kasih Kanonang telah dilakukan dengan menggunakan alat XRF (X-ray fluorescence spectrometry). Sedangkan untuk pengukuran konduktivitas dan $\mathrm{pH}$ fluida-cairan tersebut telah dilakukan dengan menggunakan alat ProLab 2000 Schott Instruments.

Hasil penelitian komposisi unsur terkandung dalam fluida-cairan, konduktivitas dan $\mathrm{pH}$ dan juga suhu fluida-cairan dari tiga lokasi manifestasi panas bumi Bukit Kasih Kanonang telah dikaji dan diungkapkan dalam artikel ini. Hasil pengukuran $\mathrm{pH}$ menunjukkan bahwa karakteristik fluida-cairan merupakan jenis elektrolit asam (acid). Hasil penelitian ini juga mengungkapkan bahwa nilai konduktivitas fluida-cairan bergantung pada nilai pHnya yang sangat ditentukan oleh komposisi asam klorida sebagai elektrolit kuat yang terdisosiasi dalam fluida-cairan tersebut.

\section{Metode Penelitian}

\subsection{Lokasi Penelitian}

Lokasi Penelitian secara administratif terletak di kelurahan Kanonang Kecamatan Kawangkoan Barat Kabupaten Minahasa, Provinsi Sulawesi Utara sebagaimana ditunjukkan pada Gambar 1. Lokasi penelitian ini terletak di daerah Panas Bumi Bukit Kasih Kanonang dengan koordinat $1^{\circ} 09^{\prime} 44.02^{\prime \prime} \mathrm{N}$ $124^{\circ} 45^{\prime} 51.06^{\prime \prime}$. Lokasi pengambilan sampel penelitian terdiri atas tiga lokasi manifestasi mata air panas Bukit Kasih Kanonang yang ditunjukkan pada Gambar 2, 3, 4 [3].

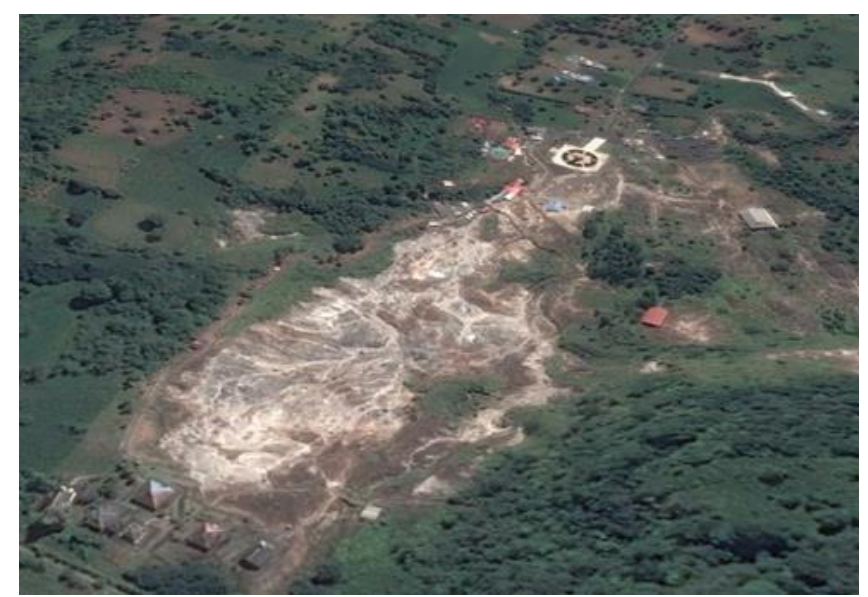

Gambar 1. Lokasi Penelitian 


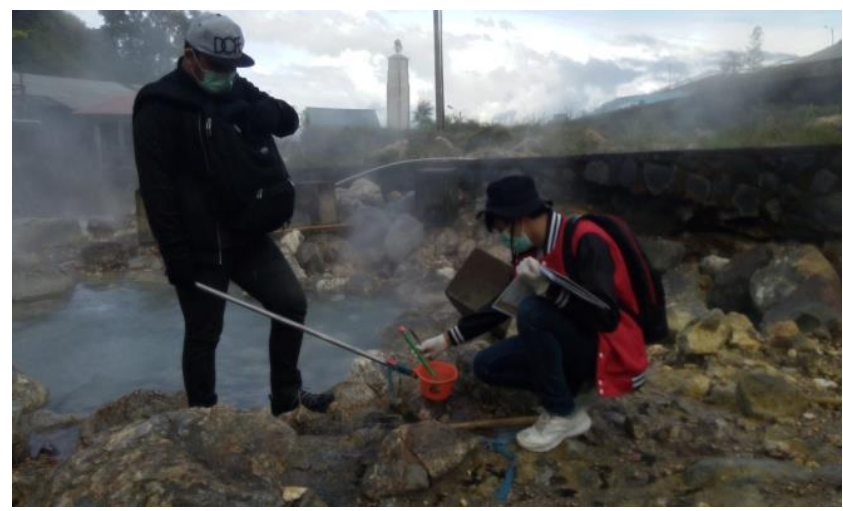

Gambar 2. Lokasi manifestasi pengambilan sampel FK 1

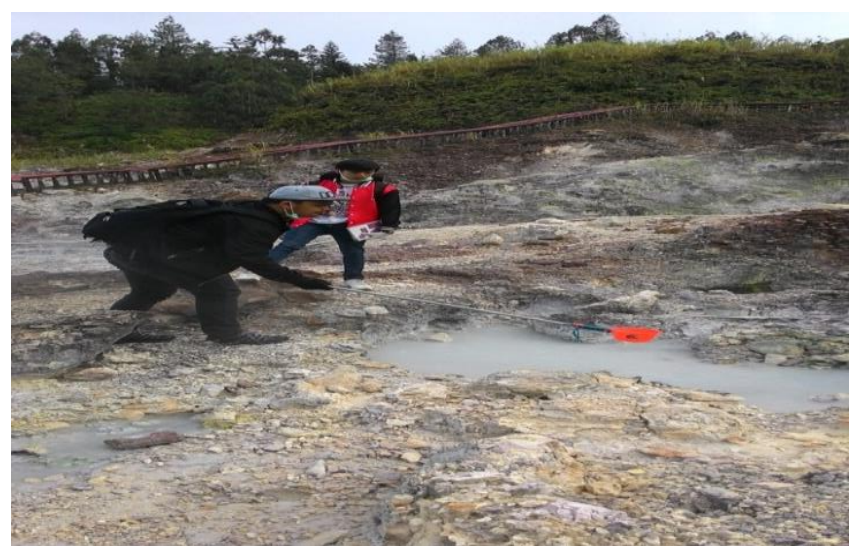

Gambar 3. Lokasi manifestasi pengambilan sampel FK 2

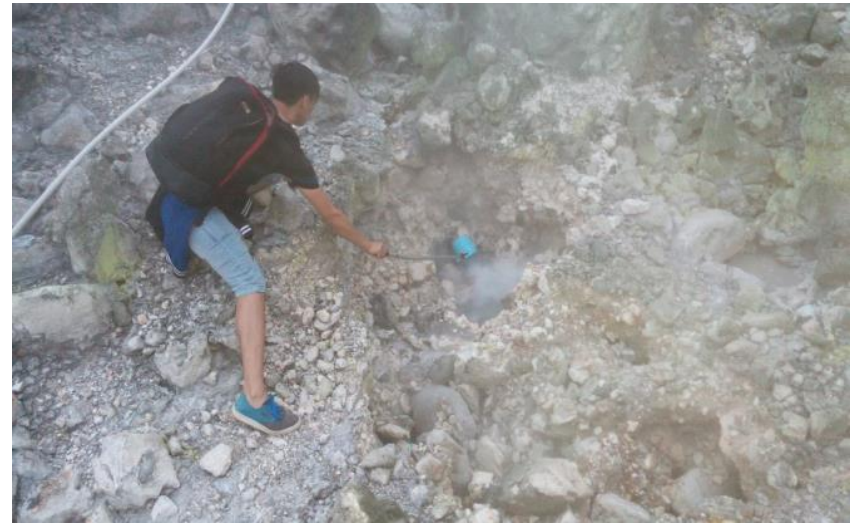

Gambar 4. Lokai manifestasi pengambilan sampel FK 3

\subsection{Persiapan Sampel (Fluida-Cairan)}

Ada tiga jenis sampel penelitian yang telah disiapkan yaitu fluida-cairan yang berasal dari tiga bagian lokasi manifestasi panas bumi yaitu lokasi FK1, FK2 dan FK3 sebagaimana ditunjukkan pada Gambar 2, 3 dan 4 di atas. Sampel ini kemudian dimasukkan dalam 6 gelas plastik sebagaimana ditunjukkan pada Gambar 5. 


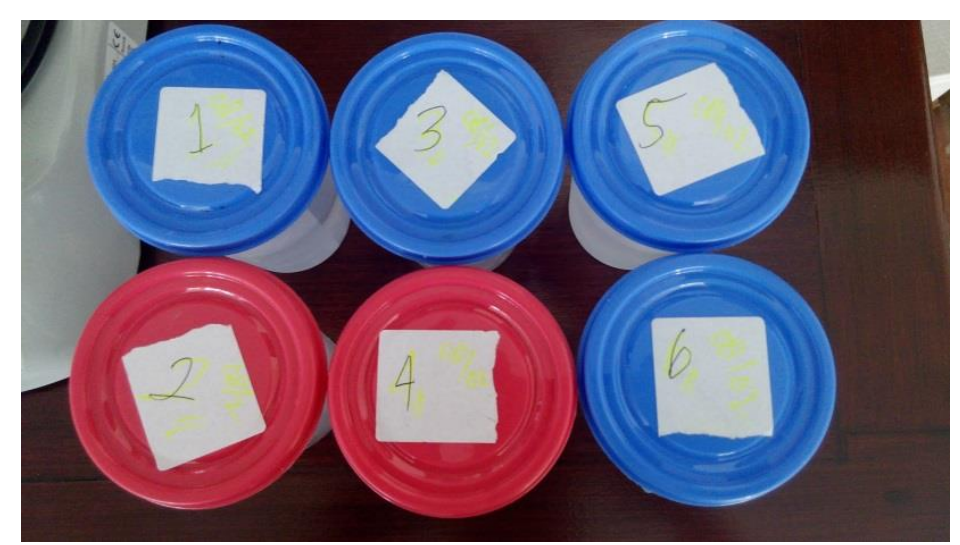

Gambar 5. Sampel Fluida-cairan: label 1,2 (lokasi FK1);label 3,4 (lokasi FK2) dan label 5,6 (lokasi FK3).

\subsection{Karakterisasi Sampel}

2.3.1 Pengukuran Konduktivitas. Pengukuran konduktivitas fluida-cairan dilakukan dengan menggunakan ProLab 2000 Schott Instruments (Gambar 6). ProLab 2000 schott instruments merupakan alat multi fungsi karena dapat mengukur empat parameter, yaitu $\mathrm{pH}$, salinitas, konduktivitas, dan D.O. Empat parameter ini dapat di ukur sekaligus dan di tampilkan melalui grafik digital. Alat ini dapat di kalibrasi otomatis maupun menggunakan cairan buffer. Alat ini menggunakan 2 jenis elektroda yaitu Elektroda Blueline digunakan untuk mengukur pH dan Elektroda LFOX 1400 untuk mengukur salinitas, konduktivitas, dan D.O.

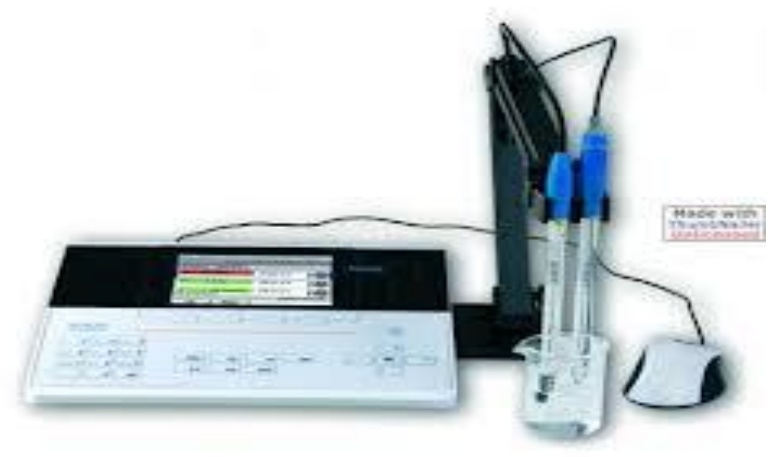

Gambar 6. ProLab 2000 Schott Instruments

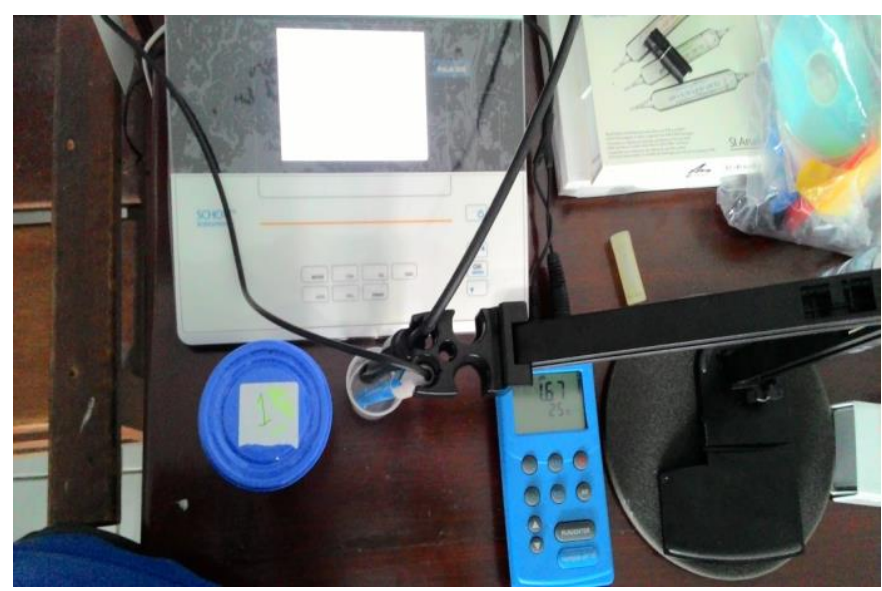

Gambar 7. Pengukuran kondukivitas fluida-cairan 
Pengukuran konduktivitas dapat dilakukan dengan menggunakan arus listrik yang dialirkan pada dua elektroda yang dicelupkan kedalam air atau larutan kimia, dan mengukur tegangan yang dihasilkan. Selama proses ini, kation berpindah ke elektroda negatif dan anion berpindah ke elektroda positif, larutan bertindak sebagai penghantar listrik. Nilai konduktivitas merupakan ukuran terhadap konsentrasi total elektrolit di dalam air. Satuan untuk resistansi adalah Ohm, konduktansi adalah Siemens (Werner von Siemens) atau mho, resistivitas adalah ohm meter dan untuk konduktivitas Siemens/cm atau mho/cm. Pengukuran konduktivitas fluida-cairan ini dilakukan di laboratorium Riset Fisika, Jurusan Fisika, FMIPA Unima.

2.3.2 Pengukuran $\mathrm{pH}$. Pengukuran $\mathrm{pH}$ dilakukan dengan menggunakan alat $\mathrm{pH}$ Meter Schott.dan ProLab 2000 Schott Instruments. pH adalah kepanjangan dari pangkat hidrogen (power of hydrogen). $\mathrm{pH}$ menyatakan tingkat keasaman atau kebasaan suatu benda yang diukur dengan menggunakan skala $\mathrm{pH}$ antara 0 hingga 14. Sifat asam mempunyai $\mathrm{pH}$ antara 0 hingga 7 dan sifat basa mempunyai nilai pH 7 hingga 14. Air murni adalah netral atau mempunyai nilai $\mathrm{pH}$ 7. $\mathrm{pH}$ air minum ideal menurut standar Departemen Kesehatan RI adalah berkisar antara 6,5 sampai 8,5. Di dalam air minum pH meter adalah suatu alat yang digunakan untuk mengukur tingkat keasaman dan kebasaan. Keasaman dalam larutan itu dinyatakan sebagai kadar ion hidrogen disingkat dengan $[\mathrm{H}+]$, atau sebagai $\mathrm{pH}$ yang artinya $-\log [\mathrm{H}+]$. Dengan kata lain $\mathrm{pH}$ merupakan ukuran kekuatan suatu asam atau untuk mengetahui apakah suatu larutan mengandung ion $\mathrm{H}+$ atau ion $\mathrm{OH}-$. Berdasarkan pengertian asambasa menurut Arrhenius bahwa suatu senyawa bersifat asam dalam air karena adanya ion $\mathrm{H}+$. Adapun suatu senyawa yang bersifat basa dalam air jika ada ion $\mathrm{OH}-\mathrm{pH}$ larutan menyatakan konsentrasi ion $\mathrm{H}+$ dalam larutan. Suatu zat asam yang di masukkan ke dalam air akan mengakibatkan bertambahnya ion hidrogen $(\mathrm{H}+)$ dalam air dan berkurangnya ion hidroksida $(\mathrm{OH}-)$. Sedangkan zat basa yang dimasukkan ke dalam air akan mengakibatkan bertambahnya ion hidroksida (OH-) dan berkurangnya ion hidrogen $\left(\mathrm{H}^{+}\right)$. Cara kerja alat ini adalah dengan cara mencelupkan kedalam air yang akan diukur (kira-kira kedalaman $5 \mathrm{~cm}$ ) dan secara otomatis alat bekerja mengukur $\mathrm{pH}$ fluida-cairan. Pada saat pertama dicelupkan angka yang ditunjukkan pada display alat ini masih berubah-ubah, untuk itu tunggulah kira-kira 2 sampai 3 menit sampai angka digital stabil. Dalam penelitian ini pegukuran $\mathrm{pH}$ menggunakan $\mathrm{pH}$ meter Schott.

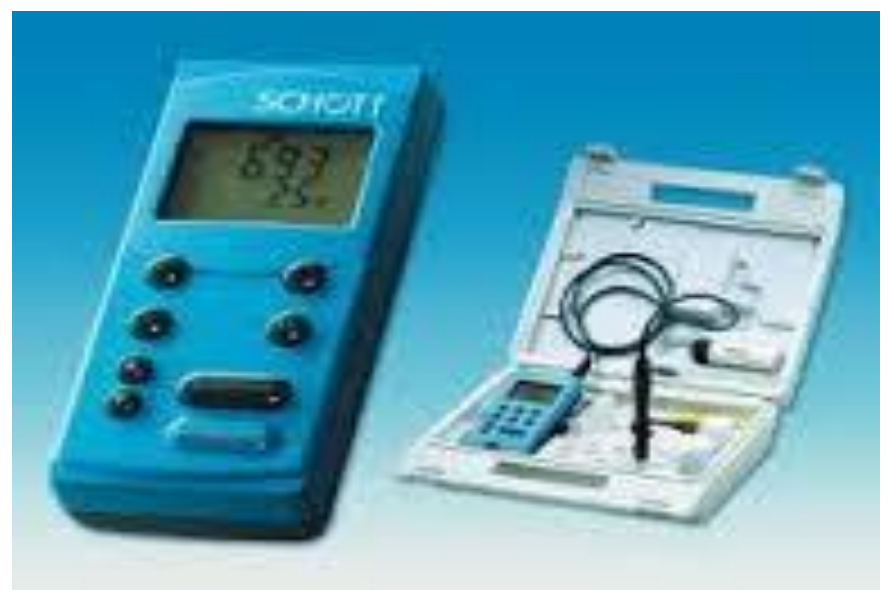

Gambar 8. pH Meter Schott 


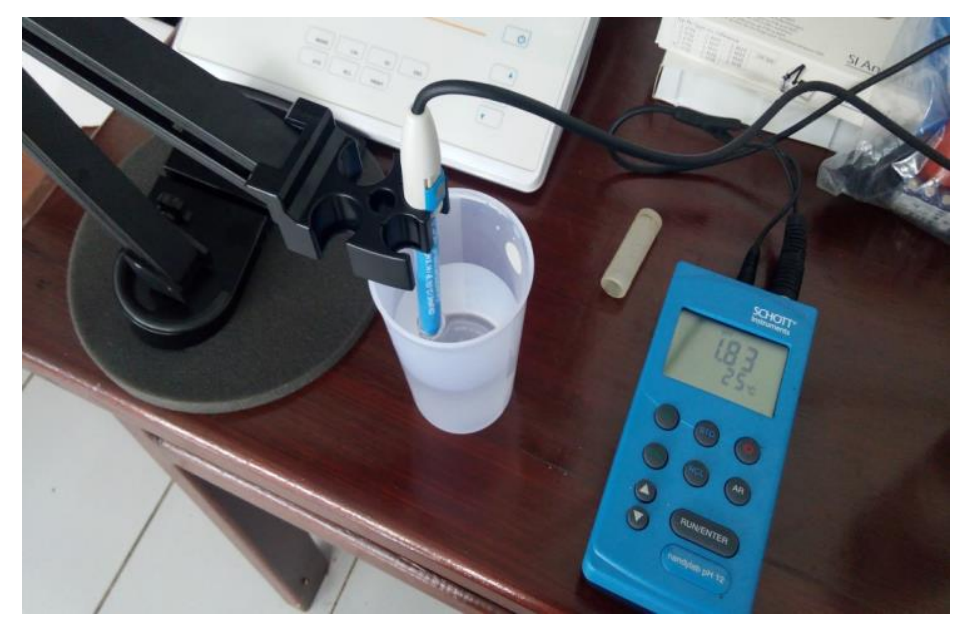

Gambar 9. Pengukuran $\mathrm{pH}$ fluida-cairan

Pengukuran $\mathrm{pH}$ fluida-cairan ini dilakukan di laboratorium Riset Fisika, Jurusan Fisika, FMIPA Unima.

2.3.3 Pengukuran $X R F$. Identifikasi komposisi unsur dalam fluida-cairan dilakukan dengan menggunakan XRF (X-ray fluorescence spectrometry). XRF (X-ray fluorescence spectrometry) merupakan teknik analisa non-destruktif yang digunakan untuk identifikasi serta penentuan konsentrasi elemen yang ada pada padatan, bubuk atau sampel cair.

X-Ray Fluorescence (XRF) adalah fenomena fisis yang terjadi ketika suatu material dikenakan sinar-X (foton) dengan energi tinggi, menumbuk suatu atom atau molekul sampel, maka energi ini akan diserap oleh atom tersebut. Dengan energi tinggi, maka elektron di sekitar inti (kulit K) terpental keluar dari orbitalnya. Dan elektron dari kulit luar kemudian turun ke orbital yang tidak terhuni/kosong untuk mengisi lubang yang ditinggalkan elektron. Energi yang diperlukan untuk melepaskan atau mengeluarkan elektron inti merupakan karakteristik elemen, dan kemudian ada energi yang dipancarkan oleh karena terjadi peristiwa transisi ini. Transisi elektron dari kulit L yang turun ke kulit $\mathrm{K}$ disebut transisi $\mathrm{K} \alpha$, sedangkan elektron pada kulit $\mathrm{M}$ yang jatuh ke kulit $\mathrm{K}$ disebut transisi $\mathrm{K} \beta$ sebagaimana ditunjukkan pada Gambar 10 [4].

Eksitasi sinar-X terjadi ketika foton sinar-X dengan energi cukup tinggi dapat mengeluarkan elektron dari kulit lebih dalam dan sehingga kemudian telah menciptakan kekosongan (vakansi). Adanya vakansi ini menimbulkan ketidakstabilan atom. Dan agar supaya atom ini kembali stabil, maka elektron dari kulit lebih luar akan berpindah ke kulit yang lebih dalam dengan proses Xfluoresensi sinar-X (X-Ray Fluoroscence) sebagimana ditunjukkan pada Gambar 11 [5].

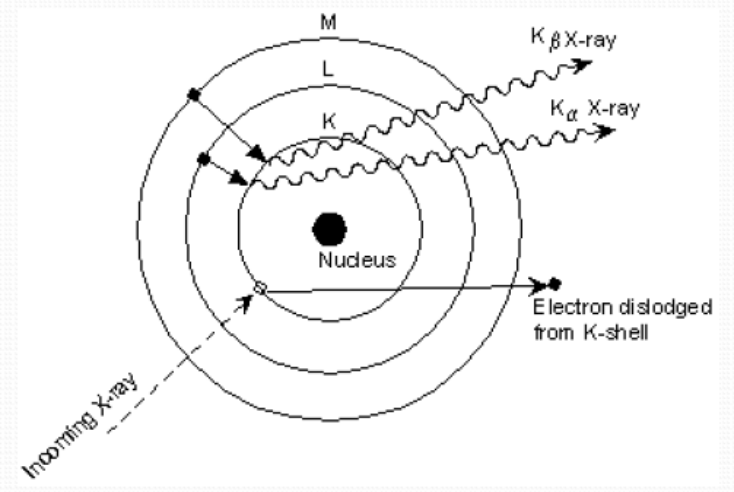

Gambar 10. Prinsip X-Ray Fluoroscence (XRF) 


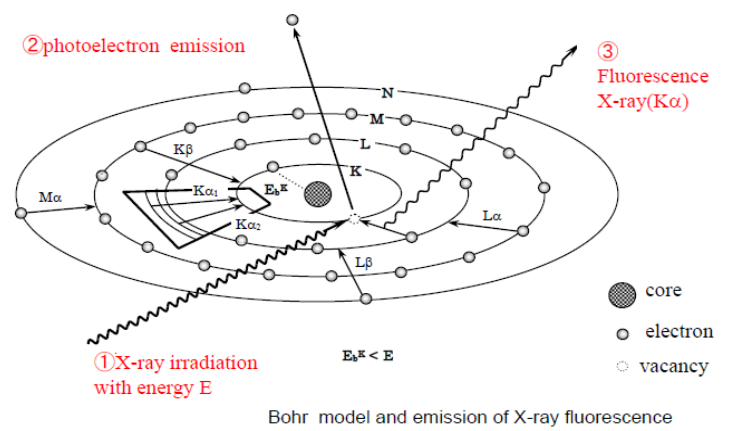

Gambar 11. Proses XRF.

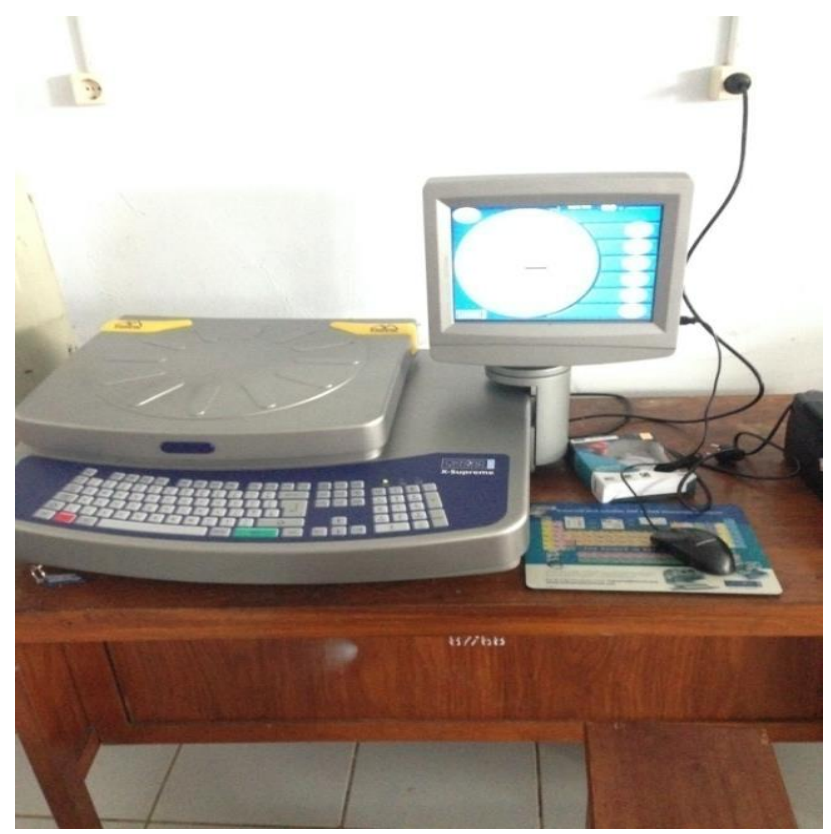

Gambar 12. Alat XRF (X-Ray Fluoresence), Oxford Instrument.

Peralatan yang digunakan untuk penentuan unsur dalam fluida-cairan dilakukan dengan menggunakan alat sebagaimana ditunjukkan pada Gambar 12. Pengukuran komposisi unsur dalam fluida-cairan ini dilakukan di laboratorium Riset Fisika, Jurusan Fisika, FMIPA Unima.

\section{Hasil dan Pembahasan}

Data geografis lokasi dan Suhu fluida-Cairan di Manifestasi Bukit Kasih Kanonang ditunjukkan pada Tabel 1.

Tabel 1. Data letak lokasi dan Suhu fluida-Cairan

\begin{tabular}{|c|c|c|c|c|}
\hline \multirow{2}{*}{ Sampel } & \multicolumn{2}{|c|}{ Koordinat (UTM) } & \multirow{2}{*}{$\begin{array}{l}\text { Elevasi } \\
\text { (m) }\end{array}$} & \multirow{2}{*}{$\begin{array}{l}\text { Suhu } \\
\text { Manifestasi }\left({ }^{\circ} \mathrm{C}\right)\end{array}$} \\
\hline & $X$ & $\mathrm{Y}$ & & \\
\hline FK 1 & 696354 & 128698 & 927 & 95,8 \\
\hline FK 2 & 696349 & 128663 & 925 & 94,9 \\
\hline FK 3 & 696349 & 128690 & 908 & 69,8 \\
\hline
\end{tabular}


Tabel 2. Komposisi dan konsentrasi unsur fluida-cairan $(\mathrm{mg} / \mathrm{kg})$

\begin{tabular}{lcccccccc}
\hline \multirow{2}{*}{ Sampel } & \multicolumn{8}{c}{ Komposisi dan konsentrasi unsur dalam fluida-cairan $(\mathrm{mg} / \mathrm{kg})$} \\
\cline { 2 - 8 } & $\mathrm{Mg}$ & $\mathrm{Al}$ & $\mathrm{Si}$ & $\mathrm{S}$ & $\mathrm{Cl}$ & $\mathrm{Ca}$ & $\mathrm{Ti}$ & $\mathrm{Fe}$ \\
\hline FK1 & 70 & 206 & 216 & 508 & 354 & 51 & 28 & 15 \\
FK2 & 138 & 654 & 2184 & 1753 & 117 & 73 & 120 & 22 \\
FK3 & 69 & 280 & 374 & 422 & 102 & 41 & 36 & 0 \\
\hline
\end{tabular}

Suhu manifestasi untuk ketiga lokasi ternyata lebih tinggi dari $50^{\circ} \mathrm{C}$, sehingga dapat dikategorikan sebagai manifestasi air panas.

Hasil identifikasi komposisi unsur yang terkandung dalam fluida-cairan dari masing-masing lokasi manifestasi FK1, FK2 dan FK3 ditunjukkan pada Tabel 2. Berdasarkan data di atas, pada lokasi FK1 memiliki nilai pH 1,67 dan nilai konduktivitasnya $9,97 \mathrm{mS} / \mathrm{cm}$, pada lokasi FK2 memiliki nilai pH 1,83 dan nilai konduktivitasnya $6,96 \mathrm{mS} / \mathrm{cm}$, sedangkan pada lokasi FK 3 nilai pH 1,94 dan nilai konduktivitasnya $3,91 \mathrm{mS} / \mathrm{cm}$. Dari grafik di atas dapat kita ketahui bahwa semakin tinggi nilai konduktivitas di Bukit kasih Kanonang, dan semakin rendah nilai $\mathrm{pH}$ di lokasi tersebut. Sebaliknya, semakin rendah nilai konduktivitas di Bukit Kasih Kanonang, semakin tinggi nilai pH di lokasi tersebut. Dari ketiga titik lokasi tersebut lokasi FK1 memiliki tingkat keasaman $(\mathrm{pH})$ dan nilai konduktivitas yang tinggi dibandingkan dengan lokasi FK2 dan lokasi FK3. Hal ini dikarenakan lokasi FK 1 memiliki nilai konduktivitas dan $\mathrm{pH}$ yang lebih tinggi dari lokasi FK2 dan FK3.

Hasil pengukuraan sifat konduktivitas/resistivitas fluida-cairan ditunjukkan pada Tabel 3. Konduktivitas fluida-cairan menurun dengan kenaikan $\mathrm{pH}$ fluida-cairan. Berdasarkan nilai $\mathrm{pH}$ maka fluida-cairan tersebut dapat dikategorikan sebagai elektrolit asam dan ion yang bertanggungjawab adalah $\mathrm{H}+$. Semakin asam suatu zat, semakin banyak ion $\mathrm{H}+$ dan semakin sedikit jumlah ion $\mathrm{OH}-\mathrm{di}$ dalam air. 13.

Secara grafik hubungan antara konduktivitas dengan $\mathrm{pH}$ fluida-cairan ditunjukkan pada Gambar

Tabel 3. Hasil pengukuran sifat konduktivitas, resistivitas, suhu dan $\mathrm{pH}$ fluida-cairan

\begin{tabular}{lllll}
\hline Sampel fluida & Konduktivitas $(\mathbf{m S} / \mathbf{c m})$ & Resistivitas $(\mathrm{k} \Omega \mathrm{cm})$ & Suhu $\left({ }^{\mathbf{0}} \mathbf{C}\right)$ & pH \\
\hline FK1 & 9,97 & 0,100 & 25 & 1,67 \\
FK2 & 0,145 & 25 & 1,89 \\
FK3 & 6,96 & 0,225 & 25 & 1,94
\end{tabular}

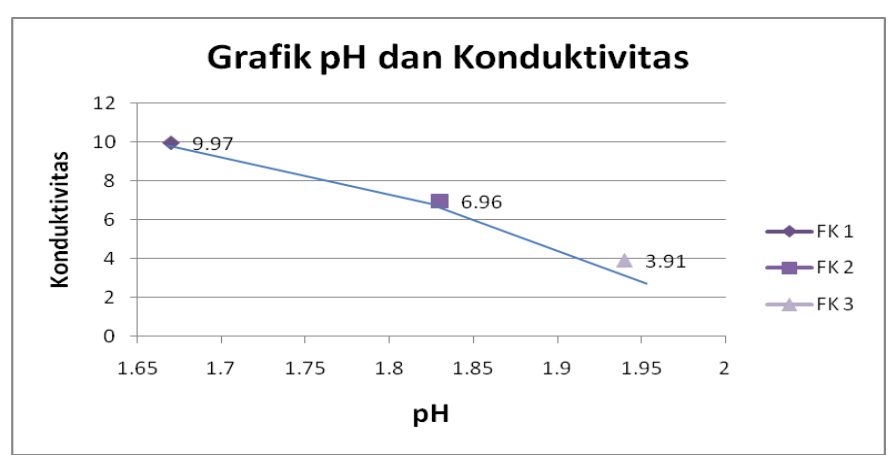

Gambar 13. Grafik hubungan konduktivitas dengan $\mathrm{pH}$ fluida-cairan 
Tabel 4. Kebergantungan nilai konduktvitas dan $\mathrm{pH}$ dan konsentrasi unsur $\mathrm{Cl}$

\begin{tabular}{cccc}
\hline Sampel & Konsentrasi unsur Cl (mg/kg) & Konduktivitas (mS/cm) & $\mathbf{p H}$ \\
\hline FK1 & 354 & 9,97 & 1,67 \\
FK2 & 117 & 6,96 & 1,89 \\
FK3 & 102 & 3,91 & 1,94 \\
\hline
\end{tabular}

Selanjutnya nilai konduktivitas dan $\mathrm{pH}$ fluida-cairan untuk unsur $\mathrm{Cl}$ ditunjukkan pada Tabel 4. Berdasarkan data di atas ternyata bahwa konduktivitas fluida di daerah Bukit Kasih Kanonang berbeda-beda dan tersebar di berbagai titik di lokasi tersebut. Sifat fisis konduktivitas fluida-cairan yang ada di manifestasi panas bumi Bukit Kasih Kanonang bergantung pada konsentrasi kandungan unsur $\mathrm{Cl}$. Harga konduktivitas dan nilai $\mathrm{pH}$ yang tinggi terdapat pada lokasi FK1 dengan nilai konduktivitas 9,97 mS/cm dan 1,67 pada nilai $\mathrm{pH}$. Beberapa faktor yang mempengaruhi sifat fisis fluida di daerah Bukit Kasih Kanonang diantaranya adalah temperatur manifestasi panas bumi, dan konsentrasi kandungan unsur.

\section{Kesimpulan dan Saran}

Berdasarkan hasil pengukuran komposisi unsur, konduktivitas, suhu dan $\mathrm{pH}$ fluida-cairan di manifestasi mata air panas Bukit Kasih Kanonang disimpulkan bahwa:

1.) Nilai konduktivitas dan $\mathrm{pH}$ dan suhu di tiga lokasi manifestasi mata air panas Bukit Kasih Kanonang berbeda. Nilai konduktivitas paling tinggi terletak di lokasi FK 1 dengan nilai konduktivitas 9,97 mS/cm, dengan nilai $\mathrm{pH}$ 1,67 serta suhu mata air panas sekitar 95,8oC.

2.) Semakin tinggi nilai konduktivitas fluida-cairan manifestasi panas bumi semakin rendah nilai pH-nya. Fluida-cairan ini dikategorikan sebagi elektrolit asam (acid).

\section{Ucapan Terima Kasih}

Ucapan terima kasih kepada Rektor Universitas Negeri Manado yang terhormat Prof. Dr. Ph. E.A. Tuerah, M.Si, DEA yang telah membiayai penelitian ini dengan Dana DIPA Unima tahun anggaran 2015. Terima kasih kepada Prof. Dr. Rudi A. Reppi M.Sc sebagai Ketua Lembaga Penelitian Unima. Terima kasih kepada Prof. Dr. C. Poluakan, MS selaku Dekan FMIPA yang telah memberikan kesempatan untuk melaksanakan penelitian ini. Akhirnya terima kasih kepada Prof. Dr. H. Taunaumang, M.Sc sebagai Kepala laboratorium Riset Fisika, FMIPA Unima.

\section{Daftar Rujukan}

[1]. Principles and Hardware of Electrolytic Conductivity Measurements, Kenneth M.Queency, Product Manager, Mettler Toledo Ingold, 2999 Washington Street Woburn, MA 01801.

[2]. Conductivity Theory and Practice, Web:www.radiometer-analytical.com

[3]. Patlus Eric Golioth, Penentuan Sifat Fisis Fluida Di Daerah Panas Bumi Bukit Kasih Kanonang, Skripsi, 2015.

[4]. X-ray fluorescence analysis, Chiya NUMAKO, Misato KAZAMA, Izumi NAKAI Chiba.

[5]. Introduction to Energy-Dispersive X-Ray Fluorescence (XRF)-An Analytical Chemistry Perspective, Peter Palmer, Department of Chemistry \& Biochemistry San Francisco State University 
JPSE, Vol. 2, No. 1, 2017, Page 29 - 38 